\title{
Understanding the Opportunities, Barriers, and Enablers for the Commercialization and Transfer of Technologies for Mine Waste Valorization: A Case Study of Coal Processing Wastes in South Africa
}

\author{
Helene-Marie Stander ${ }^{1,2, *(D)}$ and Jennifer L. Broadhurst ${ }^{1}$ (D) \\ 1 Minerals to Metals Research Initiative, Department of Chemical Engineering, Upper Campus, \\ University of Cape Town, Rondebosch, 7700 Cape Town, South Africa; jennifer.broadhurst@uct.ac.za \\ 2 Centre for Bioprocess Engineering Research, Department of Chemical Engineering, Upper Campus, \\ University of Cape Town, Rondebosch, 7700 Cape Town, South Africa \\ * Correspondence: stnhel008@myuct.ac.za
}

check for

updates

Citation: Stander, H.-M.; Broadhurst, J.L. Understanding the Opportunities, Barriers, and Enablers for the Commercialization and Transfer of Technologies for Mine Waste Valorization: A Case Study of Coal Processing Wastes in South Africa. Resources 2021, 10, 35. https:// doi.org/10.3390/resources10040035

Academic Editor: Xianlai Zeng

Received: 5 March 2021

Accepted: 9 April 2021

Published: 14 April 2021

Publisher's Note: MDPI stays neutral with regard to jurisdictional claims in published maps and institutional affiliations.

Copyright: (c) 2021 by the authors. Licensee MDPI, Basel, Switzerland. This article is an open access article distributed under the terms and conditions of the Creative Commons Attribution (CC BY) license (https:/ / creativecommons.org/licenses/by/ $4.0 /)$.

\begin{abstract}
The mining and minerals beneficiation industries produce large volumes of waste, the land disposal of which can lead to harmful environmental emissions and a loss of valuable resources. Globally, researchers are developing technologies for recovering valuable minerals and converting mine waste into a resource with market value. However, university-developed technological innovations to long-term environmental problems can be difficult to transfer to the mining industry. This paper focuses on the barriers and enablers to technology transfer in the South African mining industry using the valorization of coal processing waste as a case study. Data and information derived from interviews with relevant experts and published literature were used to gain a better understanding of the landscape of waste valorization technology implementation. Results indicated that financial considerations and demonstration of technical feasibility will be vital in determining the success of technology transfer, as will a changing perception of waste and its value within the sector. Original equipment manufacturers (OEMs) and boutique waste processors were identified as potential commercial partners for further development and commercial implementation of university-developed waste valorization technologies within the mining sector.
\end{abstract}

Keywords: mine waste valorization; technology transfer; barriers and enablers; stakeholder roles

\section{Introduction}

Technology transfer (or diffusion) is a complex process that encompasses the transfer of technological objects, codified knowledge, and tacit knowledge from one organization to another, as well as the acceptance and implementation of the technology in the receiving organization [1-5]. Teece [4] defines the process of technology transfer as what occurs between the first encounter between technology originator and the adopter and the final implementation of the technology, with Souder et al. [6] defining a technology as adopted when an adopter has a "strong emotional and financial commitments to [a technology's] routine use". When universities and other research organizations develop technologies, it is often with a view to eventual transfer and commercial adoption.

Understanding technology transfer from research organizations, specifically universities, to the industry is crucial when the intentions of the technologies are to improve the environmental and/or social characteristics of the industry and is important for maximizing the return on investment to both funders and society at large [7-11]. Social/environmental technologies, such as technologies for improving resource efficiency and establishing a circular economy, can have additional barriers to implementation since they often address issues that are currently externalized, and benefits are not always sufficient to drive adoption [12-14]. One such externalized issue is mining waste. 
Mining and primary ore processing operations produce large volumes of waste. These are normally disposed of in surface waste deposits such as tailings dams and heaps or backfilled into disused workings leading to the risk of environmental pollution [15-21]. Of particular concern in the case of wastes generated from sulfide-bearing hard rock ores and coal is the formation of acid rock drainage on exposure to air and water [22-24]. Acid rock drainage (ARD) causes water pollution and soil sterilization $[25,26]$. Many South African coals have a significant sulfide mineral content, which reports to both the discards and slurry waste during processing, rendering them potentially ARD generating $[26,27]$. (Coal processing produces waste of different size fractions. The coarse material $(>1 \mathrm{~mm})$ is called discards, while the fine material presents as slurry and is traditionally disposed of as tailings.). While current disposal practices, such as co-disposal and waste compaction, aim to minimize ARD generation by limiting air and water ingress $[16,19,28]$, and advances in cementing technology are being made [29,30], they have yet to be proven effective in eliminating the generation of polluting discharges in the long-term, and continual monitoring will thus be required $[15,18,31]$. Furthermore, future disturbances by artisanal miners or land developers, for instance, could expose sulfidic minerals and thus increase the risk of ARD generation.

Avoiding land disposal through repurposing and reprocessing mine waste for other uses has the potential to remove these long-term ARD pollution risks. The approach, called valorization, views waste as a secondary resource rather than as an unwanted material, consistent with the circular economy- and resource efficiency principles [32-35]. For waste to be turned into an asset and these benefits to be realized, innovative technologies and innovative application of existing technologies are needed. Large-scale waste valorization efforts are currently impeded by a lack of industry-wide information on waste characteristics, and therefore potential uses of mine wastes, although European efforts are focused on improving the situation $[32,36,37]$. The need for updated legal frameworks and societal acceptance has also been noted [32,38,39]. To help overcome some of these barriers, research funding initiatives such as Horizon 2020, EIT Jumpstarter, and WasteAid's Circular Economy network [40-43] provide opportunities for accessing funding and support. Commercialization and implementation are imperative if waste valorization technologies are to make a difference in mining landscapes and beyond. Technology transfer is necessary for implementation to take place.

Technology transfer of sustainability technologies to the mining industry is a subject that has received little explicit attention, and Suppes and Heuss-Aßbichler [32] have noted the need for mapping barriers to the development of waste valorization technologies. There also appears to be limited research on the factors influencing university technology commercialization and transfer in South Africa, particularly in the context of coal waste management. This is an important gap in the literature since the mining industry is likely to be more careful with technology implementation due to the high capital cost associated with mining technologies, the long lead time of implementation as well as the highly cyclical nature of the industry itself $[44,45]$. In addition, waste valorization is a sustainability-related technology and, therefore, likely to face additional barriers that are not always immediately apparent.

The objective of this study was, therefore, to develop an enhanced understanding of the factors influencing the commercialization and transfer of university-originated waste valorization technologies to the South African coal industry, as well as the potential roles of different stakeholders. This was achieved through a qualitative analysis of the perspectives and experiences of experts in, or associated with, the South African coal industry. It is envisaged that this understanding will support the development of a defensible business case as well as a technology commercialization and transfer approach for application to waste valorization technologies. Identification of potential implementation partners was also considered a priority since the early involvement of a commercial partner in technology development improves the likelihood of successful development and transfer $[6,46,47]$. 


\section{Method}

\subsection{Interviews as a Method}

Investigations of technology transfer for sustainability found in the literature have made use of a variety of methods, such as structured surveys/questionnaires, focus groups, and interviews $[9,12,14,47,48]$. This list indicates that qualitative research methods are common in investigating technology transfer in sustainability environments. For this study, insights into the perspectives and opinions of experts on the opportunities, barriers, and enablers for the transfer of coal waste valorization technologies in the South African context were gained through the thematic analysis of transcripts derived from semi-structured interviews. In accordance with Bogner et al. [49] and Robson [50], semi-structured interviews are an efficient way of learning about issues that certain groups of people have intimate knowledge of, such as their motives and opinions. This type of interview also allows interviewees to explain their reasoning and support their observations with data, which in turn allows for richer interpretations than most surveys.

Expert interviews are a special class of interviews that can be used to gain organizational or subject-specific knowledge from a group of individuals who are active in a field [51-53]. These interviews are particularly useful when they engage experts on quasi-technical and organizational matters, i.e., expert knowledge gained through practical experience that cannot be answered by a more technical research design or document analysis [53,54]. These subject-specific and quasi-technical issues include aspects such as common methods employed by, or corporate opinions of, an organization or discipline [49]. This provides insights that would have been difficult to glean by other methods.

In this study, coal industry executives and consultants were interviewed along with individuals who were intimately involved with environmental and waste-related technology implementation in the coal industry, as well as people active in applied coal research. These individuals ostensibly had the most knowledge of the functioning of the coal industry and how it relates to environmental technologies. Further details on the selection of respondents and the interview process are provided in Sections 2.1 and 2.2, respectively. Data analysis (Section 2.3) was conducted using thematic analysis, and the results compared with information from published literature to identify synergies and/or anomalies peculiar to the case study under investigation.

\subsection{Respondent Selection}

In accordance with literature guidelines [54,55], respondents were selected based on stakeholder representation and access, and a variety of sub-groupings active in the coal industry were represented. These included corporate executives from both coal majors and junior miners, individuals who have been part of technology implementation in the coal industry, researchers active in the coal industry, as well as consultants to the South African coal industry. A total of 29 experts were contacted, resulting in 16 interviews. Consistent with the recommendations of Lincoln and Guba [56], cited in Patton [55], interviews were conducted until theoretical saturation was reached. Theoretical saturation represents the point where more interviews do not add new perspectives or opinions. It is therefore not necessary to conduct additional interviews after having reached that point [55]. The fact that theoretical saturation was reached relatively quickly may be reflective of how closely-knit the South African coal industry is. The method of respondent identification and the number of declined interviews mean that sampling was not completely random. Individuals uninterested in environmental technologies may have been overrepresented in the population that declined interviews, for instance. Some sampling effects may therefore be present.

Also, the nature of interviews and the respondents selected means that in many cases, the information elicited from stakeholders are only their opinion on what may transpire, based on their knowledge of their organizations and the industry as a whole, rather than the lived experience of someone who has successfully implemented. The testimonies of the technology implementers are therefore especially important for deriving useful 
information. That said, all stakeholders provided their own rich perspectives of the coal industry and its relationship with waste and new technologies. They contributed their own understandings to piece together the bigger picture.

A breakdown of the respondents that were interviewed is shown in Table 1. To protect individuals' identities, no personal identifiers are made known unless specifically requested. The two technology implementers were a developer and provider of waste management technologies that have been implemented on multiple mines; and an academic who has successfully commercialized and licensed a waste valorization technology and was in the process of commercializing another at the time of interviewing. The related commodity executive implemented waste valorization technology successfully on the mine where they worked. The coal major executives interviewed were from four of South Africa's five coal major firms: Anglo American, South 32, Exxaro, and Sasol. They mainly headed or were involved in technical departments of these companies, but one was involved with project development. The respondents from junior mining companies headed their engineering- and environmental departments, respectively. Of the consultants interviewed, one had a technical focus, one contributed an industry perspective, one was from an environmental consultancy, and one had a project focus. The researchers interviewed were from industrial research organizations in South Africa. Respondents who declined interviews included a consultant, a technology implementer, two researchers, four major coal executives, and five junior coal executives. This indicates that it was particularly hard to secure interviews with coal juniors and the testimonies of the two coal junior executives are therefore particularly important.

Table 1. Stakeholders interviewed.

\begin{tabular}{ll} 
Technology implementers & 2 \\
Coal major executives & 5 \\
Related commodity executive/implementer & 1 \\
Coal junior executives & 2 \\
Consultants to the coal mining industry & 4 \\
Researchers active in coal-related research & 2 \\
\hline
\end{tabular}

\subsection{Interview Method}

Interviews were conducted over Skype, using telephone calls in the case of technical difficulty with Skype, and in person. In two cases, respondents invited colleagues along to the interview, resulting in impromptu focus groups being conducted. In all cases, the interviews were recorded. Questions ranged from specific organizational processes to respondents' opinions on industry matters, as shown in Box 1.

\subsection{Analysis}

The interviews were analyzed using thematic analysis [57]. The thematic analysis was conducted semantically, therefore focusing on surface meanings and from a realist perspective, which means that the words of participants are viewed as reflecting the participants' meanings [57]. The data were also analyzed to give an overall picture of the themes present in the data and inductively, which means that the themes considered were not derived from theory but from ideas encountered in the data set [57]. This means that less interactional detail was required than for conversation analysis, for instance, and the transcriptions did not account for tone of voice or other non-verbal communication. In addition, some simplifications of the data were considered acceptable to improve readability. Examples include the correction of minor grammar errors (such as is/are mistakes), removal of oft-repeated stop phrases such as "actually" in cases where the word choice did not make sense, and the removal of repeated words. Transcription and analysis were conducted using NVivo software. 
Box 1. Question list.

- How do you make the decision to pilot a new technology? (Criteria? People involved)

- How do you make the decision to implement a new technology?

- What if someone from outside the company wants to implement?

- Is there some sort of standardization in the process of bringing a technology to implementation in the coal industry, or does everybody follow their own process?

- How do you fund your projects? (Bank loan? Company balance sheet?)

- Which players (organizations) would be the most likely to implement value-from-waste technologies? [Mines? Boutique waste processors? Community-based business? Etc? Why? Examples? Experience?]

- Do you think the process of implementation of value-from-waste technologies will be easy or difficult? Why?

- What are the most important barriers to implementation?/What will be the difficulties of implementation?

- Which are the most important drivers of implementation?

- What is your opinion on the legal side of implementing value-from-waste projects?

- How would the barriers and drivers be different for different implementers?

- What do you think needs to happen for implementation to become more likely or easy? Overcome barriers?

- $\quad$ Are there any stakeholders whose buy-in are especially important? What group of stakeholders do you need buy-in from?

- Have you implemented something similar and what were the issues?

- Would you consider developing processes with research bodies, such as universities? What are the issues?

- Do you think that reprocessing coal tailings for other purposes is a good idea?

- Do you have anything to add that we have not discussed?

\section{Results and Discussion}

The results are discussed under two main headings, each reflecting the research objectives: barriers and enablers to transfer (Section 3.1); the roles important stakeholders can be expected to play in transfer (Section 3.2). Themes under each heading are then discussed and supported by published literature.

\subsection{Barriers and Enablers}

The results of the study have shown that there are several factors, both technical and non-technical, which constrain or facilitate the commercialization and transfer of potentially feasible technologies for the valorization of coal processing wastes. The main influencing factors can be broadly grouped into the following sub-themes, discussed in Sections 3.1.1-3.1.4: the technical aspects of technology development; the business case for implementation; the legislative and regulatory climate; and corporate culture and values.

\subsubsection{Technology Development and Demonstration}

Technology must be proven to be effective before it can be implemented in practice since success at a laboratory scale does not guarantee success at a pilot or demonstration scale. This is according to 11 of the 16 respondents. Nine respondents then described piloting and demonstration plants as the way to prove a technology. This process is, however, long and expensive according to all the coal major executives, a consultant, and a researcher, so the availability of funding and partners with experience in scaling-up was discussed as important considerations.

Assuming that the technology is proven, industry awareness of the technology and its efficacy was believed to be an important driver of implementation by two-thirds of the respondents. This was considered especially important when some in the industry have pre-conceived ideas around the efficacy of a technology, such as the case of the froth flotation of coal. As a technology implementer remarked: "We spend a lot of time to show people what we've achieved, how it works and where it's implemented. You know, that whole concept of seeing is believing. That helps tremendously." Allowing industry 
stakeholders access to demonstration or industrial-scale plants to experience it working is, therefore, an important part of a technology awareness strategy. Other ways of creating awareness in the industry were also proposed by the respondents: presentations at industry assemblies such as the Fossil Fuel Foundation (https: / / www.fossilfuel.co.za/ (accessed 12 April 2021)) conferences and Coaltech (https:/ / coaltech.co.za/ (accessed 12 April 2021)) meetings; and publicizing lab testing results of different coals. These observations by the respondents agree with the literature, which states that technology risk is easier to assess in technologies that are easy to understand and in cases where representatives of a company have opportunities to interact with the technology $[4,6]$.

Half of the respondents mentioned that proven technologies must be tested for efficacy in their own setting, with their own materials and infrastructure. This means that even when a technology is proven in principle, mines would like to be convinced that it will work on their own material and in the context of their own plant. This aspect is especially important when working with waste. Six respondents mentioned that robustness is needed due to waste's inherent variability and uncontrolled nature. The related commodity executive commented that the technology needs to produce a consistent product from material with a wide compositional range since the composition of waste can vary significantly between different areas of a waste dump. They put it as follows: "I mean it is like standing there in the dark and not knowing what you are going to get. That's what dealing with waste is like." Waste compositions for different mines are also likely to vary fairly significantly (see, for example, Moyo et al. [58]).

These observations by the respondents are consistent with findings reported in the literature. As highlighted by Souder et al. [6], a prospective technology implementer has to assess the technology based on whether it is appropriate for their application, as well as whether they can assume the level of technological risk inherent in the technology at its stage of development. Consequently, a technology's stage of development is of utmost importance in technology transfer, as the first implementation is the riskiest and most expensive [4,45,47]. As noted by Grano et al. [59] and Teece [4], the scale-up process is uncertain and mature technologies are more likely to be successfully transferred since the difficulties with implementation have been ironed out in different contexts, and the technology is well-understood. As one of the coal major executives put it: "It's rare that you see a total new technology in a total new greenfields." Technology reliability and maintenance requirements are also easier to estimate when technologies are mature [6]. Implementing new technologies opens a company up to technology risk.

A potential barrier to technology transfer efforts specific to the coal mining industry, identified by almost half of respondents, is the lack of appropriate technical expertise within mining companies due to their focus on core business and business strategy. Six respondents noted that mines prefer to focus on their core business, which is producing and selling commodities, to the exclusion of other business models. This has meant that they do not develop technologies to sell to other mines and therefore do not staff adequate research and development $(R \& D)$ departments to engage in specialized technology development, according to three coal major executives and a technology implementer. As one of the coal major executives noted, "We're not into developing the technology to sell it to other mining companies. They're our competition." Four of the respondents suggested that buying well-supported robust technologies off-the-shelf is a preferable approach for most mines, as opposed to funding development or developing new technologies in-house.

Given the lack of technical skills at mining companies, management may find it difficult to appreciate the potential of technologies or the technical risk that will have to be managed. This increases the transfer risk since literature reports that an important contributor to success is an adopting organization that has the skills to understand the technology, implement it, and operate it [3-5,59-62]. It is unlikely that those in the adopting organization will support the technology and its implementation if the advantages of the technology are unclear, unvalued, or intangible, all of which are more likely if the 
management team has little technical background and it is likely to be dismissed or end in failure $[3,47,60,63]$.

\subsubsection{Business Case}

Regardless of in-house technical expertise, all 16 of the respondents agreed about the necessity of having a convincing business case and considered techno-economic viability as the biggest determinant of successful technology transfer. Two respondents even started the interview with an exposition of the importance of a business case before the first question could be asked. The published literature corroborates this sentiment (see for example $[4,6,47,64-66])$.

Respondents mentioned that a sound business case would either reflect a reduction in a company's costs and liabilities, or an increase in income, with two-thirds of the respondents mentioning the reduction of disposal costs and liabilities as an appropriate focus for a business case for waste valorization. Inherent in the concept of a convincing business case is an economic market for the product that the producer can access, as stated by six respondents. A major coal executive related an instance where his team had a product, but where the customer was not convinced about the appropriateness of it for their application, and the product consequently failed. As one consultant put it: "The hurdles are going to be project-specific, but the fundamental hurdle is that there's got to be an economic market for the product." Having a market can therefore be considered important to be able to sell the product and recoup the costs incurred in development and implementation.

As discussed in Section 3.1.1, technology development can be expensive. Almost all the respondents mentioned that the cost associated with technology development and implementation, including financing and transfer costs, can be a significant barrier, especially when financial resources are constrained, such as for mining juniors. This finding is consistent with literature $[3,4,45,60,62,63,67]$. In addition to the financial costs of technology development, the cost in terms of time and effort of developing and piloting a technology was also seen as a significant barrier to implementation by 12 respondents. In South Africa specifically, the dearth of funding for scale-up and scarcity of other resources such as skilled personnel is a significant barrier [68]. Most timelines that were mentioned were between eight and 15 years. Three respondents also noted that long timelines open companies to the risk that the market might not be available anymore by the time the technology is mature enough to implement. This then presents a significant financial risk due to the high cost of technology development mentioned earlier.

A common indicator of the viability of a project is the internal rate of return (IRR) that it achieves [45], despite the fact that a focus on the IRR of a project does not recognize less tangible benefits associated with waste valorization, such as a reduction in occupied land for waste storage [69]. One researcher mentioned that an IRR of around $17.5 \%$ could be considered the hurdle rate for technologies in the South African mining industry. Research by Johnston [45] places the hurdle rate for implementation of technologies in the mining industry higher, at an IRR of $23 \%$, even when a technology has other environmental benefits as well. Lamprecht [65] places the hurdle IRR for innovative technologies even higher, at $30 \%$, to offset the associated risk and costs. While the researcher's figure is somewhat lower than the figures mentioned in the literature, it is still significant. High IRR's to the exclusion of other benefits could be required in environments where there is difficulty in accessing debt financing [66] or because of the tangible financial repercussions of failure [62].

Three respondents mentioned that a possible barrier to achieving high IRR's in the case of mine waste valorization is the need to achieve economies of scale. Tailings impoundments, while large and capable of generating significant ARD burden, might not be big enough to achieve the economies of scale that a mining company would require for investment. Eight respondents mentioned that the large distances between coal waste heaps, the fact that not all coal mines produce fines, which reduced the number of poten- 
tial sources, as well as ownership issues with waste may present commercial barriers to combining waste heaps to achieve economies of scale.

\subsubsection{Regulatory Environment}

Consistent with literature reports $[47,70]$, two-thirds of respondents considered South African legislation to be a potential driver for mines to implement value-from-waste technologies. This is largely because stringent waste management legislation can significantly increase the cost of traditional waste disposal methods, thereby improving the business case for implementing waste valorization technology. An example from the South African National Environmental Management: Waste Act 59 of 2008 that was mentioned by five respondents includes regulations that require lining of tailings dams for disposing of mine waste containing hazardous components. As one consultant noted: "you don't see many people with slimes dams, for example, because it is just too complicated to actually try and get permission for a slimes dam. So now all of a sudden, even though filter presses are expensive, people realize slimes dams are expensive." Five respondents also mentioned that involvement in developing environmental technologies should create goodwill toward the mining company at certain government departments, making interest from mining companies and consequently implementation more likely.

Eleven respondents, however, mentioned that some aspects of legislation also act as barriers to the implementation of waste valorization efforts. One such aspect, mentioned by half of the respondents, is the requirement to get licenses and permission for activities from various government entities when changing or adding activities. One example of licensing and permissions that was mentioned by four respondents is legislation that requires permission from the National Energy Regulator of South Africa or the minister for setting up waste-burning power plants bigger than $1 \mathrm{MW}$ for their own use. This makes adopting an obvious value-from-waste option difficult and onerous. Another aspect that was mentioned by four of the respondents was that they thought that South African legislation, in general, puts unreasonable expectations on mines. For instance, one technology implementer mentioned that the requirement for water discharge purity was higher than the purity of the river into which it is discharged. Other legal issues that were mentioned were issues with liability for, and ownership of, waste which can stifle collaboration between mines; expenses associated with legislation that hurt mines' profitability; and social and labor plan-related requirements, which also adds costs. A review of South African law on waste valorization indicates that it has only recently been explicitly legislated [71], despite having been espoused in the National Waste Management Strategy for many years [72]. The respondents did not question the objectives of the laws but commented on the fact that they were too ambitious, too rigid, restricted the mines' options, and used compliance exclusively instead of complementing with incentives.

\subsubsection{Corporate Values and Culture}

According to half of the respondents, business culture-related barriers to waste valorization within the coal sector include corporate inertia, bureaucracy, and pre-conceived ideas, all of which need to be challenged and changed if a novel waste-related technology that reprocesses or repurposes bulk waste material is to be implemented. In general, it appears that waste is not seen as imminently valuable in the coal industry for anything other than the residual coal it contains. Ideas of waste being hazardous, being gotten rid of, and as a liability were voiced by half of the respondents. When asked about valuefrom-waste technologies, the dominant conceptions were of extracting the residual coal or mineral value from the waste or burning coal waste to recover residual energy value as opposed to considering the bulk material as a resource. One notable exception was the case mentioned by a coal major executive of an entire waste heap being worked away by being repurposed, but this was not the norm. Interestingly, while most of the respondents were open to new technologies unlocking interesting value propositions, they did not think that any currently existed. 
The interview data also indicated that, in order to understand the culture within the South African coal industry, it is important to understand that it views itself as undervalued by outsiders and under pressure. Half of the respondents mentioned challenges such as depleting coal resources, increasingly onerous legal requirements, volatile commodity prices and looming social and environmental liabilities. For some in the industry, this pressure has made them defensive, as shown by two respondents who, unprovoked, defended the industry and explained its importance in detail. According to the arguments presented by Sizhen et al. [66], these pressures may have the effect of making a business case based on financial returns exceedingly important for the implementation of new technology since mines feel that their livelihoods are at risk.

Nevertheless, these pressures can also be a force of positive change. As a technology implementer put it: "because of the legislation, and of the pressure that environmental bodies put on mining houses, they're forced to do something, because the public does not like acid water, they do not like pollution. If it's screened on Carte Blanche [a South African investigative journalism television program], people see it and then there's a lot of pressure to reduce this pollution and footprints." These views are consistent with literature reports which show that implementation of technology is influenced by the interests and experience of the managers of organizations and by the social background, knowledge, and acceptance of the implementing staff, among other factors $[3,5,46,47,61,73]$. Company values are influenced by that of the surrounding communities and society at large, so societal values and corporate reputation may be drawn on to support technology implementation $[3,74]$.

\subsection{Stakeholder Roles}

Technology transfer is a complex process involving several stages and stakeholders. Figure 1 shows stages and role players that are commonly involved in technology transfer [6]. These stages are: prospecting, which involves finding or disseminating technology; developing, which involves adapting technology for implementation; trialing, the process of testing it onsite; and adoption, the final stage of implementation. These stages are iterative, and some aspects can run in parallel [6]. Common role players in the process are: sponsor, developer, adopter, disseminator, and implementer [6,75] but the same organization or person can play multiple roles, and different organizations can co-operate to play the same role.

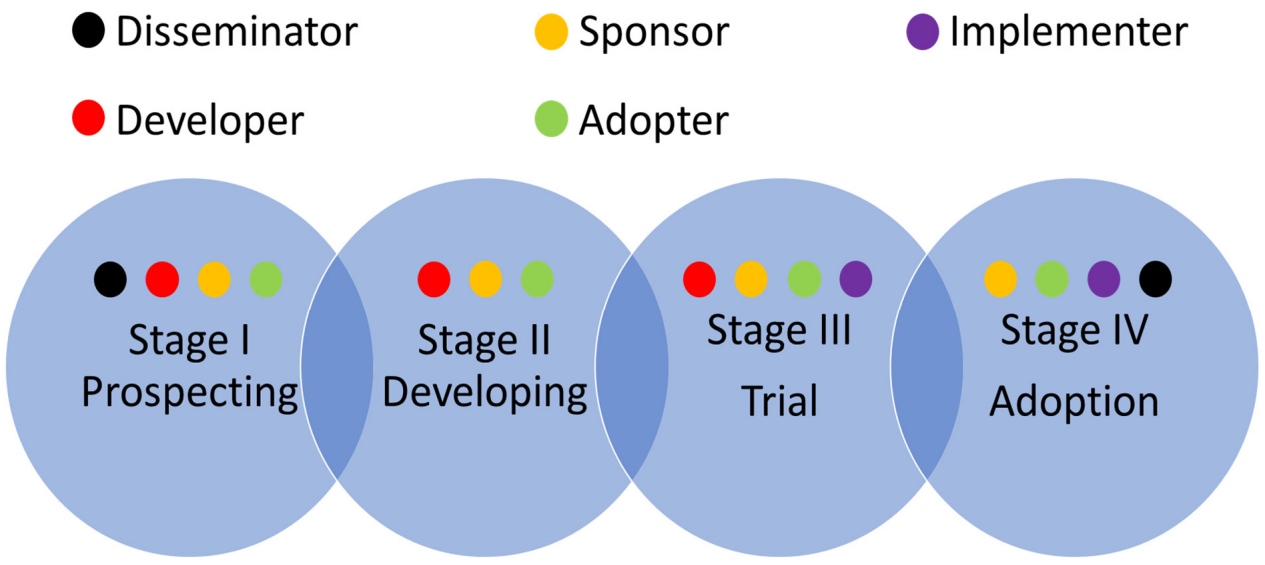

Figure 1. The process of technology transfer loosely based on a diagram by Souder et al. (1990) [6].

In the transfer of university-developed technologies for the valorization of waste generated by coal mines, these same stages and stakeholders are expected to be key. Universities and their technology transfer offices can play the roles of disseminator and developer. University technology transfer offices in particular can be important bodies in the technology transfer landscape and provide essential services to the process [7]. Mining operations or organizations are also key stakeholders who can play the roles of the adopter, sponsor, and historically developer and implementer. Additional direct 
role players identified in this research are original equipment manufacturers, who can play the roles of developer, implementer, and perhaps even adopter; commercial research institutions to co-play the role of the developer; and communities to play the role of the adopter, if the technology is sufficiently robust. The roles of these external stakeholders are discussed in more detail in Sections 3.2.1-3.2.3.

\subsubsection{Role of Mines}

In the past, universities have worked with mines and big mining companies to commercialize technologies [76]. The mining companies took on the roles of co-developer, adopter, sponsor, and implementer. However, findings from this study indicate that this approach may not be appropriate anymore. According to respondents, the mining business model is not technology development but raw materials production (see discussions in Section 3.1.1), which means that mining houses have systematically moved resources away from technical departments and have outsourced technical functions. Mines have focused on their capacity to produce ores and minerals and, according to two consultants and a coal major executive, reduced their research and development and specialized technical functions.

As the business model of mines has led them to disinvest in specialized technical functions, it has also meant that mines are not developing alternative business strategies. A third of respondents suggested that the business strategies of mines are important in the implementation decision. As a coal major executive noted, the business strategy of a mine is not manufacturing or electricity production which means that they do not have intimate knowledge of those businesses and markets. The executive also noted that mining companies will therefore also not have their corporate structures set up in a way that will support the marketing and sales of other (non-core) products. These perspectives suggest that the lack of corporate structures to support ventures outside the narrow mining business model increases the risk and effort associated with waste valorization ventures. This means that management may rightly be reluctant to enter such businesses.

Another potential barrier to mine implementing is the tendency of waste valorization to produce a small profit stream compared with the mine's core business. A technology implementer, researcher, and consultant all emphasized that the small profit stream is one of the key reasons that waste reprocessing has historically been poorly managed at mines. According to these respondents, the results of neglect have then sometimes been mistaken for technology failure.

Mines can therefore be technology sponsors but will most likely transfer the implementer, and perhaps even the technology adopter role, to another organization. Two major coal executives mentioned that they are aware of companies that push much of the technical research that they require on to trusted original equipment manufacturers (OEMs), also known as technology providers, who they then hire to test and implement any technologies that they may need. The OEMs thereby become technical mediators for the mines. Likewise, one technology implementer's company became the technology adopter on behalf of the mines they work with. Nevertheless, a third of the respondents mentioned that mines, or holders of the waste to be processed, should be intimately involved with the process of implementation because they will derive value and are best placed to understand the composition of their waste.

\subsubsection{Role of OEMs and Commercial Waste Processors}

As indicated above, half of the respondents considered OEMs to be in a better position to implement, operate and maintain the equipment for waste reprocessing than the mine. In line with this, one technology implementer and four major coal executives thought that a well-respected OEM or technology provider would be a better partner for technology commercialization than the mines themselves. Examples by respondents suggest that this is indeed the case. In almost all the cases mentioned where a value-from-waste technology was implemented on a mine and with the help of the mine, the OEM or 
waste processor was the party that implemented the technology, runs it, and maintains it. Respondents indicated that OEMs already have the business strategy (they service multiple mines), experience, technical skills, contacts, and credibility with the industry to be able to commercialize technologies successfully and can thereby avoid the risk of mining companies failing to operate waste valorization operations effectively (see Section 3.2.1). One coal major executive also believed that it would be appropriate for an OEM to fund part of the technology development since they would draw advantage from its success. The appetite of OEMs for acting as commercial partners of universities and other research organizations would have to be tested; however, since they fall outside of the sample that was interviewed, and issues such as the ownership of intellectual property (IP) are likely to be important considerations in such partnerships.

One coal industry researcher suggested that commercial waste processors may also be a good option as partners for commercializing value-from-waste technologies. In the case mentioned by a coal major executive where an entire waste heap was worked away, this was also done by an external party who took ownership of the waste stream as well as the profits arising from the processing. Sylvania, a commercial waste processor which runs scavenger plants between chrome production facilities and their waste disposal heaps [77], was cited as an example of a similar business model. The arguments advanced for having a commercial waste processor take over the waste stream were similar to that of enlisting OEMs.

\subsubsection{Role of Third Parties}

In the discussion thus far, mines and OEMs or commercial waste processors have been identified as the primary partners of the university. Nevertheless, according to the literature, these are unlikely to be the only entities of interest in technology commercialization and transfer process. Both respondents and literature indicated that other entities, such as transfer offices and other commercial research institutions, are also likely to play a role in successful commercialization and transfer [14,64,78]. For instance, a quarter of respondents suggested that national science councils, such as the Council for Scientific and Industrial Research (CSIR) in South Africa, have more experience in applied research than university researchers and could be helpful research partners when early commercialization research needs to be done. Given the emphasis placed on technology scale-up, discussed in Section 3.1.1, this is likely to be a critical partnership.

Lastly, seven respondents mentioned that if the technology can be proven to be sufficiently simple to operate and robust, the opportunity to have communities take ownership of the technology would be welcomed as something to include in a mine's social and labor plan. However, four respondents mentioned that, even in such cases, the mine would have to ensure that the community service provider is able to handle the technology from a technical point of view and may need to help the organization to obtain certain permissions and approvals. An external technical oversight body may, therefore, still be needed. Two respondents noted that mines would still want to provide oversight to the community service provider because of the long-term liability associated with mining waste.

\section{Conclusions}

Mining waste is produced in large volumes and can be hazardous to the environment and surrounding communities. Valorizing mining waste will reduce the land footprint taken up by mining waste as well as the risks associated with it. Despite these advantages, the commercial implementation of such technologies is limited. This study set out to understand the drivers and barriers to waste valorization technology implementation, with a specific focus on the South African coal mining industry, and to understand the roles of different stakeholders in the industry as well as their potential roles in technology implementation. 
The results of this research have shown that there are a variety of factors constraining and/or driving the adoption of waste valorization technologies within the South African coal sector. These factors, furthermore, tend to be highly interlinked, making for a complex landscape for implementation. For instance, the complexity of the technology impacts the development timelines as well as the cost of development, thus influencing the appetite that a potential implementer is likely to have for implementing the technology. This aspect, therefore, has technical, economic, and business implications. Results show that traditional techno-economics is likely to dominate the considerations in the transfer and implementation of waste valorization technologies in the South African coal mining industry. This, coupled with the narrow perspective on waste and valorization, is likely to make advocating for a technology based on environmental grounds alone unsuccessful. Robust business cases and demonstrations of technical feasibility and suitability are thus important factors for waste valorization technology implementation success in the sub-sector. Furthermore, while increasingly stringent regulations should, in theory, provide an incentive for the implementation of waste valorization technologies, the onerous and restrictive nature of the current regulatory landscape in South Africa serves to make the impact uncertain in practice. South Africa's regulatory environment, therefore, simultaneously enables and hinders the implementation of waste valorization technologies.

The study has also indicated that mining companies are unlikely to be implementers of environmental technologies since technology development is not part of their business model, and their technical support bases have eroded. Original equipment manufacturers (OEMs) and boutique waste processors are potentially better placed to be commercial partners in technology transfer from universities since they are the technical mediators for mining companies. They also service multiple mining companies and therefore have a bigger market for the technology than a single mining company. In addition, applied research organizations such as the CSIR may be helpful in technology development.

While the findings of this study are directly applicable to the South African coal mining industry, they could be extended to other mining sectors and geographic regions. The barriers and drivers and their relative significance will, however, vary to a lesser or greater extent, according to the specific risks associated with different commodities, ore bodies, and geopolitical contexts.

Author Contributions: Conceptualization, H.-M.S. and J.L.B.; methodology, H.-M.S.; investigation, H.-M.S.; data preparation, H.-M.S.; analysis, H.-M.S.; writing-original draft preparation, H.-M.S.; writing-review and editing, H.-M.S. and J.L.B.; visualization, H.-M.S.; supervision, J.L.B.; project administration, J.L.B.; funding acquisition, J.L.B. All authors have read and agreed to the published version of the manuscript.

Funding: This research was funded by the South African Water Research Commission and the South African Research Chairs Initiative of the Department of Science and Technology and National Research Foundation (NRF) of South Africa (Minerals Beneficiation). Any opinion, finding, and conclusion or recommendation expressed in this material is that of the authors, and the NRF does not accept any liability in this regard. The APC was funded by Jennifer Broadhurst.

Institutional Review Board Statement: The study was conducted according to the guidelines of the Declaration of Helsinki, and ethics approval has been granted in terms of the University of Cape Town Faculty of Engineering and the Built Environment Ethics in Research process (approved on 2 September 2015).

Informed Consent Statement: Informed consent was obtained from all subjects involved in the study.

Data Availability Statement: The data is held in a data repository but cannot be published due to confidentiality agreements with the participants.

Acknowledgments: The authors would like to thank the respondents for their participation in this study. Those prepared to be mentioned were Peter Hand from Isandla Consulting, Johan de Korte from the CSIR, Xavier Prevost from XMP Consulting, Jannie Maree from ROC Water Technologies, Jeremy Mann from the Centre for Minerals Research at UCT, Marinus du Plessis at the time from Exxaro, Michael Solomon who is an independent mining and metals professional, and Phil Tanner 
from Digby Wells. Their insights have been invaluable. All authors have read and agreed to the published version of the manuscript.

Conflicts of Interest: The authors declare no conflict of interest.

\section{References}

1. Bozeman, B. Technology transfer and public policy: A review of research and theory. Res. Policy 2000, 29, 627-655. [CrossRef]

2. Hipkin, I.; Bennett, D. Managerial perceptions of factors influencing technology management in South Africa. Technovation 2003, 23, 719-735. [CrossRef]

3. Kostova, T.; Roth, K. Adoption of an organizational practice by subsidiaries of multinational corporations: Institutional and relational effects. Acad. Manag. J. 2002, 45, 215-233.

4. Teece, D.J. Technology transfer by multinational firms: The resource cost of transferring technological know-how. Econ. J. 1977, 87, 242-261. [CrossRef]

5. Zander, U.; Kogut, B. Knowledge and the speed of the transfer and imitation of organizational capabilities: An empirical test. Organ. Sci. 1995, 6, 76-92. [CrossRef]

6. Souder, W.E.; Nashar, A.S.; Padmanabhan, V. A guide to the best technology-transfer practices. Technol. Transf. 1990, 15, 5-16. [CrossRef]

7. Good, M.; Knockaert, M.; Soppe, B.; Wright, M. The technology transfer ecosystem in academia. An organizational design perspective. Technovation 2019, 82-83, 35-50. [CrossRef]

8. Harmon, B.; Ardishvili, A.; Cardozo, R.; Elder, T.; Leuthold, J.; Parshall, J.; Raghian, M.; Smith, D. Mapping the university technology transfer process. J. Bus. Ventur. 1997, 12, 423-434. [CrossRef]

9. Lai, W.-H. Willingness-to-engage in technology transfer in industry-University collaborations. J. Bus. Res. 2011, 64, 1218-1223. [CrossRef]

10. Lowe, R.A.; Gonzalez-Brambila, C. Faculty entrepreneurs and research productivity. J. Technol. Transf. 2007, 32, 173-194. [CrossRef]

11. Wright, M.; Birley, S.; Mosey, S. Entrepreneurship and University Technology Transfer. J. Technol. Transf. 2004, 29, 235-246. [CrossRef]

12. Adams, K.T.; Osmani, M.; Thorpe, T.; Thornback, J. Circular economy in construction: Current awareness, challenges and enablers. Proc. Inst. Civ. Eng. 2017, 170, 15-24. [CrossRef]

13. Guerin, T.F. An Australian perspective on the constraints to the transfer and adoption of innovations in land management. Environ. Conserv. 1999, 26, 289-304. [CrossRef]

14. Trencher, G.; Bai, X.; Evans, J.; McCormick, K.; Yarime, M. University partnerships for co-designing and co-producing urban sustainability. Glob. Environ. Chang. 2014, 28, 153-165. [CrossRef]

15. Hamberg, R.; Maurice, C.; Alakangas, L. The formation of unsaturated zones within cemented paste backfill mixtures-Effects on the release of copper, nickel, and zinc. Environ. Sci. Pollut. Res. 2018, 25, 20809-20822. [CrossRef]

16. Behum, P.T.; Chugh, Y.P.; Lefticariu, L. Management of coal processing wastes: Studies on an alternate technology for control of sulfate and chloride discharge. Int. J. Coal Sci. Technol. 2018, 5, 54-63. [CrossRef]

17. Chen, Q.; Sun, S.; Liu, Y.; Qi, C.; Zhou, H.; Zhang, Q. Experimental and numerical study on immobilization and leaching characteristics of fluoride from phosphogypsum based cemented paste backfill. Int. J. Miner. Metall. Mater. 2021. [CrossRef]

18. Villain, L.; Alakangas, L.; Öhlander, B. The effects of backfilling and sealing the waste rock on water quality at the Kimheden open-pit mine, northern Sweden. J. Geochem. Explor. 2013, 134, 99-110. [CrossRef]

19. Van Zyl, D.; M, S.; Digby, C.; Fleury, A.; Kyeyune, S. Mining for the Future Appendix A: Large Volume Waste Working Paper; Mining, Minerals and Sustainable Development: London, UK, 2002.

20. Owen, J.R.; Kemp, D.; Lèbre, E.; Svobodova, K.; Pérez Murillo, G. Catastrophic tailings dam failures and disaster risk disclosure. Int. J. Disaster Risk Reduct. 2020, 42, 101361. [CrossRef]

21. Zhang, Q.; Zhang, J.; Wu, Z.; Chen, Y. Overview of solid backfilling technology based on coal-waste underground separation in China. Sustainability 2019, 11, 2118. [CrossRef]

22. Broadhurst, J.L.; Harrison, S.T.L. A desulfurization flotation approach for the integrated management of sulfide wastes and acid rock drainage risks. In Proceedings of the 10th International Conference on Acid Rock Drainage \& IMWA Annual Conference, Santiago, Chile, 21-24 April 2015; pp. 1-11.

23. Leathen, W.W.; Braley, S.A.; McIntyre, L.D. The role of bacteria in the formation of acid from certain sulfuritic constituents associated with bituminous coal II. Ferrous Iron Oxidising Bacteria. Appl. Microbiol. 1953, 1, 65-68. [CrossRef]

24. Leathen, W.W.; Braley, S.A.; McIntyre, L.D. The role of bacteria in the formation of acid from certain sulfuritic constituents associated with bituminous coal I. Thiobacillus Thiooxidans. Appl. Microbiol. 1953, 1, 61-64. [CrossRef]

25. McCarthy, T.S. The impact of acid mine drainage in South Africa. S. Afr. J. Sci. 2011, 107. [CrossRef]

26. McCarthy, T.S.; Pretorius, K. Coal Mining on the Highveld and Its Implications for Future Water Quality in the Vaal River system. In Proceedings of the International Mine Water Conference, Pretoria, South Africa, 19-23 October 2009; Water Institute of Southern Africa's Mine Water Division \& International Mine Water Association: Pretoria, South Africa, 2009 ; pp. 56-65.

27. Eberhard, A. The Future of South African Coal: Market, Investment, and Policy Challenges; Freeman Spogli Institute for International Studies at Stanford University: Stanford, CA, USA, 2011. 
28. Park, I.; Tabelin, C.B.; Jeon, S.; Li, X.; Seno, K.; Ito, M.; Hiroyoshi, N. A review of recent strategies for acid mine drainage prevention and mine tailings recycling. Chemosphere 2019, 219, 588-606. [CrossRef]

29. Barati, S.; Tabatabaie Shourijeh, P.; Samani, N.; Asadi, S. Stabilization of iron ore tailings with cement and bentonite: A case study on Golgohar mine. Bull. Eng. Geol. Environ. 2020, 79, 4151-4166. [CrossRef]

30. Liu, L.; Xin, J.; Huan, C.; Qi, C.; Zhou, W.; Song, K.I.I.L. Pore and strength characteristics of cemented paste backfill using sulphide tailings: Effect of sulphur content. Constr. Build. Mater. 2020, 237, 117452. [CrossRef]

31. Akcil, A.; Koldas, S. Acid Mine Drainage (AMD): Causes, treatment and case studies. J. Clean. Prod. 2006, 14, 1139-1145. [CrossRef]

32. Suppes, R.; Heuss-Aßbichler, S. How to identify potentials and barriers of raw materials recovery from tailings? Part I: A UNFC-compliant screening approach for site selection. Resources 2021, 10, 26. [CrossRef]

33. Bocken, N.; de Pauw, I.; Bakker, C.A.; van der Grinten, B. Product design and business model strategies for a circular economy. J. Ind. Prod. Eng. 2016, 33, 308-320. [CrossRef]

34. Kirchherr, J.; Reike, D.; Hekkert, M. Conceptualizing the circular economy: An analysis of 114 definitions. Resour. Conserv. Recycl. 2017, 127, 221-232. [CrossRef]

35. Nzihou, A.; Lifset, R. Waste valorization, loop-closing, and industrial ecology. J. Ind. Ecol. 2010, 14, 196-199. [CrossRef]

36. Blasenbauer, D.; Bogush, A.; Carvalho, T.; Cleall, P.; Cormio, C.; Guglietta, D.; Fellner, J.; Fernández-Alonso, M.; Heuss-aßbichler, S.; Huber, F.; et al. Knowledge Base to Facilitate Anthropogenic Resource Assessment; COST (European Cooperation in Science \& Technology): Vienna, Austria, 2020.

37. Žibret, G.; Lemiere, B.; Mendez, A.; Cormio, C.; Sinnett, D.; Cleall, P.; Szab, K.; Carvalho, M.T. National mineral waste databases as an information source for assessing material recovery potential from mine waste, tailings and metallurgical waste. Minerals 2020, 10, 446. [CrossRef]

38. Tayebi-khorami, M.; Edraki, M.; Corder, G.; Golev, A. Re-thinking mining waste through an integrative approach led by circular economy aspirations. Minerals 2019, 9, 286. [CrossRef]

39. Brady, K. Mining and Metals and the Circular Economy; ICMM (International Council on Mining \& Metals): London, UK, 2016.

40. European Union. Horizon 2020 Raw Materials. 2021. Available online: https://ec.europa.eu/programmes/horizon2020//en/ area/raw-materials (accessed on 30 March 2021).

41. European Raw Materials Alliance. About ERMA. 2021. Available online: https://erma.eu/ (accessed on 30 March 2021).

42. EIT Raw Materials. EIT 2021Jumpstarter. 2021. Available online: https:/ / eitrawmaterials.eu/ eit-jumpstarter/ (accessed on 30 March 2021).

43. Wilson, M. Launch of WasteAid's Circular Economy Network in South Africa. Available online: https://wasteaid.org/launch-ofwasteaids-circular-economy-network-in-south-africa/ (accessed on 30 March 2021).

44. Botas, M.; Nkosi, A.; Williams, S.; Sethiya, P.; Mokone, M.; Craven, R.; Sasongko, T.; Cucinotta, F.; Rossouw, A.; Doherty, K. Mine 2018: Tempting Times. Available online: https:/ /www.pwc.com/id/mine-2018 (accessed on 30 March 2021).

45. Johnston, O.R. Analysis of Energy Efficiency in South Africa's Primary Mineral Industry: A Focus on Gold. Master's Thesis, University of Cape Town, Cape Town, South Africa, 2012.

46. Davis, F.D.; Bagozzi, R.P.; Warshaw, P.R. User acceptance of computer technology: A comparison of two theoretical models. Manag. Sci. 1989, 35, 982-1003. [CrossRef]

47. Greiner, M.A.; Franza, R.M. Barriers and bridges for successful environmental technology transfer. J. Technol. Transf. 2003, 28, 167-177. [CrossRef]

48. Mishra, J.L.; Chiwenga, K.D.; Ali, K. Collaboration as an enabler for circular economy: A case study of a developing country. Manag. Decis. 2019. [CrossRef]

49. Bogner, A.; Littig, B.; Menz, W. Expert Interviews-An Introduction to a New Methodological Debate. In Interviewing Experts; Bogner, A., Littig, B., Menz, W., Eds.; Palgrave Macmillan: Houndmills, UK, 2009; pp. 1-15. ISBN 978-0230-20679-3.

50. Robson, C. Real World Research, 2nd ed.; Blackwell Publishing: Oxford, UK, 2002.

51. Bogner, A.; Menz, W. The Theory-Generating Expert Interview: Epistemological Interest, Forms of Knowledge, Interaction. In Interviewing Experts; Bogner, A., Littig, B., Menz, W., Eds.; Palgrave Macmillan: Houndmills, UK, 2009 ; pp. 43-79. ISBN 978-0230-20679-3.

52. Littig, B. Interviewing the Elite-Interviewing Experts: Is There a Difference? In Interviewing Experts; Bogner, A., Littig, B., Menz, W., Eds.; Palgrave Macmillan: Houndmills, UK, 2009; pp. 98-113. ISBN 978-0230-20679-3.

53. Stander, H.-M.; Broadhurst, J.L. Reflection on Method of Expert Interviews for Research on Sustainable Minerals Development in Africa. In Sustainable Development in Africa: Concepts and Methodological Approaches; Nagao, M., Broadhurst, J.L., Edusah, S., Awere, K.G., Eds.; Spears Media Press: Denver, CO, USA, 2019; pp. 137-155. ISBN 978-1-942876-45-8.

54. Morgan, M.G. Use (and abuse) of expert elicitation in support of decision making for public policy. Proc. Natl. Acad. Sci. USA 2014, 111, 7176-7184. [CrossRef]

55. Patton, M. Designing Qualitative Studies. In Qualitative Evaluation and Research Methods; Sage Publications, Inc.: Beverley Hills, CA, USA, 1990; pp. 186-196.

56. Lincoln, Y.S.; Guba, E.G. Naturalistic Inquiry; SAGE Publications Ltd.: Newbury Park, CA, USA, 1985; ISBN 0-8039-2431-3.

57. Braun, V.; Clarke, V. Using thematic analysis in psychology. Qual. Res. Psychol. 2006, 3, 77-101. [CrossRef] 
58. Moyo, A.; Filho, J.R.D.A.; Harrison, S.T.L.; Broadhurst, J.L. Implications of sulfur speciation on the assessment of acid rock drainage generating potential: A study of South African coal processing wastes. Minerals 2019, 9, 776. [CrossRef]

59. Grano, S.R.; Ralston, J.; Skinner, W.; Fornasiero, D. Successful technology transfer from the P260 project-Case studies on plant implementation of generic flotation research. In Proceedings of the Tenth Mill Operators' Conference, Adelaide, Australia, 12-14 October 2009; pp. 12-14.

60. Hilson, G. Barriers to implementing cleaner technologies and cleaner production (CP) practices in the mining industry: A case study of the Americas. Miner. Eng. 2000, 13, 699-717. [CrossRef]

61. Kimberly, J.R.; Evanisko, M.J. Organizational innovation: The influence of individual, organizational, and contextual factors on hospital adoption of technological and administrative innovations. Acad. Manag. J. 1981, 24, 689-713.

62. Lee, J.; Win, H.N. Technology transfer between university research centers and industry in Singapore. Technovation 2004, 24, 433-442. [CrossRef]

63. Nikolaou, I.E.; Evangelinos, K.I. A SWOT analysis of environmental management practices in Greek Mining and Mineral Industry. Resour. Policy 2010, 35, 226-234. [CrossRef]

64. Ankrah, S.N.; Burgess, T.F.; Grimshaw, P.; Shaw, N.E. Asking both university and industry actors about their engagement in knowledge transfer: What single-group studies of motives omit. Technovation 2013, 33, 50-65. [CrossRef]

65. Lamprecht, S. Commercialisation Strategy and Funding; University of Cape Town: Cape Town, South Africa, 2012.

66. Sizhen, P.; Yan, L.; Han, S.; Ping, Z. Studies on Barriers for Promotion of Clean Technology in SMEs of China. Chin. J. Popul. Resour. Environ. 2005, 3, 9-17. [CrossRef]

67. Rochon, G.L.; Niyogi, D.; Fall, S.; Quansah, J.E.; Biehl, L.; Araya, B.; Maringanti, C.; Valcarcel, A.T.; Rakotomalala, L.; Rochon, H.S.; et al. Best management practices for corporate, academic and governmental transfer of sustainable technologies to developing countries. Clean Technol. Environ. Policy 2010, 12, 19-30. [CrossRef]

68. Gericke, M. Trends and Opportunities-Mining and Metal Waste; Mintek: Randburg, South Africa, 2014.

69. Godfrey, L.; Oelofse, S.; Phiri, A.; Nahman, A.; Hall, J. Mineral Waste: The Required Governance Environment to Enable Reuse; Council for Scientific and Industrial Research: Pretoria, South Africa, 2007.

70. Perkmann, M.; Tartari, V.; McKelvey, M.; Autio, E.; Broström, A.; D’Este, P.; Fini, R.; Geuna, A.; Grimaldi, R.; Hughes, A.; et al. Academic engagement and commercialisation: A review of the literature on university-industry relations. Res. Policy 2013, 42, 423-442. [CrossRef]

71. Department of Environmental Affairs. Regulations Regarding the Exclusion of a Waste Stream or a Portion of a Waste Stream from the Definition of Waste; Department of Environmental Affairs: Pretoria, South Africa, 2018; pp. 4-12.

72. Department of Environmental Affairs. National Waste Management Strategy; Department of Environmental Affairs: Pretoria, South Africa, 2011.

73. Lang, J.C. Social context and social capital as enablers of knowledge integration. J. Knowl. Manag. 2004, 8, 89-105. [CrossRef]

74. Brønn, P.S.; Vidaver-Cohen, D. Corporate Motives for Social Initiative: Legitimacy, Sustainability, or the Bottom Line? J. Bus. Ethics 2008, 87, 91-109. [CrossRef]

75. Spann, M.S.; Adams, M.; Souder, W.E. Measures of Technology Transfer Effectiveness: Key Dimensions and Differences in Their Use by Sponsors, Developers and Adopters. IEEE Trans. Eng. Manag. 1995, 42, 19-29. [CrossRef]

76. Broadhurst, J.L.; Cohen, B.; Deglon, D.; Franzidis, J.-P.; Gaylard, P.; Harris, M.; O'Connor, C. Proposal for the establishment of: The South African Minerals to Metals Research Institute (SAMMRI); SAMMRI: Cape Town, South Africa, 2009.

77. Sylvania Platinum Limited. Our Business. 2015. Available online: http://www.sylvaniaplatinum.com/b/b_i.php (accessed on 21 November 2018).

78. McAdam, R.; Miller, K.; McAdam, M.; Teague, S. The development of University Technology Transfer stakeholder relationships at a regional level: Lessons for the future. Technovation 2012, 32, 57-67. [CrossRef] 